\title{
AN INTERCULTURAL PERSPECTIVE OF ERROR CORRECTION AND STUDENT LEARNING IN ENGLISH AS A FOREIGN LANGUAGE CONTEXT
}

\author{
Esther Somé-Guiébréi \\ Ecole Normale Supérieure, \\ BP 34 Saaba, \\ Burkina Faso
}

\begin{abstract}
:
Error correction is an essential component of language learning. It takes different forms that can affect language learning either positively or negatively. In the foreign language learning context, where the classroom is the only environment where the learners encounter the target language, error correction must be central to learning. It can easily be a demotivation factor to language learning. In this paper, the author examines error correction in High schools in Burkina Faso. The article explores how teachers deal with error corrections in the classroom and error treatment on student learning. The author conducted a qualitative study using classroom observations and interviews with teachers and students as data collection methods.
\end{abstract}

Keywords: foreign language learning/teaching, error treatment, interlanguage, fossilization, stabilization

\section{Introduction}

This study explores the treatment of errors in classroom settings in Burkina Faso. Like several foreign language contexts, high school students in Burkina Faso often lack English language learning motivation. That lack of motivation seems quite common among English Language learners, mostly among high school students who skip their English language classes or are physically present but absent in mind. The lack of motivation of learners can be traced back, among other things, to the treatment of students' errors in the classroom. As a teacher educator, the author has noted throughout her interactions with in-service and preservice teachers that there seems to be a consensus among local teachers on the view of errors as a significant learning opportunity. However, that view of errors does not always translate into positive approaches to error treatment. Mistakes are often treated in isolation and hardly lead to a significant learning opportunity.

i Correspondence: email somee.uk@gmail.com 
The author's error analysis classes inspired this study. Over the years, the author has noticed that teachers often have severe comments about their learners. Teachers perceive the latter as 'lazy' 'uninterested' and 'unmotivated' in the classroom. Hence, the author decided to conduct a few in-classroom observations and concluded that teachers often play a significant role in demotivating and uninteresting their students in classroom activities. Among the many ways teachers affect their learners' motivation is the approach used in treating the latter's errors.

The literature mainly addressed the role of teachers in foreign language learning. However, the African context has mostly been unexplored. This study situates the African context in the literature by analyzing teachers' treatment of EFL learners' errors in a francophone African country.

In this study, the author examines approaches used in addressing students' errors in the classroom. She examines the following research questions: How do teachers perceive and treat students' misconceptions? How do students respond to error treatment? The hypothesis is that teachers rarely have a positive reinforcement attitude towards students' errors, and learners show little to no interest in error treatment. The methodology is mixed, and the methods of data collection are questionnaires to students, classroom observation, and interviews with teachers and teacher supervisors, and students.

\section{An interlanguage approach to error treatment}

Interlanguage theory was developed in 1972 by Selinker to understand the learners' errors in their L2 learning process. It came as a reaction to contrastive analysis and error analysis that presented a few weaknesses in dealing with the challenges faced by second language learners.

Selinker (1972) defined interlanguage as a linguistic system that considers transitional linguistic patterns and rules from native language to target language. Selinker argues that interlanguage occurs with adult language learners.

However, Tarone (2012) revisited this view developed by Selinker and argued that children also produce interlanguage similarly to adult language learners. He claims that in a study involving French immersion programs in Canada, the "children produced interlanguages that were fossilized, and had substantial influence from NL [native language] transfer" (p. 4).

Al-Khresheh (2015) also described interlanguage as "a separate language having its own linguistic system" (p. 123). It is a process in which the learner develops a new linguistic system that is neither from the native language nor from the target language". Tarone (2012) adds that "the linguistic system of interlanguage encompasses not just phonology, morphology, and syntax, but also lexis, pragmatics, and discourse." (p. 2)

Selinker (1972) introduced the notion of fossilization, and Selinker \& Lakshamana (1992) added the idea of stabilization as critical elements to interlanguage. Stabilized errors "are the ones that eventually disappear as the learner makes progress, whereas fossilized 
errors are those which do not disappear entirely regardless of the input and exposure given to the learner" (Fauziati, 2011: p.28). They are "permanent endstate of learners' interlanguage implying that learners never overcome this endstate of interlanguage regardless of learners' ability, learning opportunities, or their motivation to learn" (Lee, 2009). Han (2005) asserts that adult learners are predisposed to fossilization for biological and cognitive reasons, and that characteristic does not apply to children. Fauziati (2011) also adds that grammatical errors are dynamic. He argues that fossilized pedagogical interventions can contribute to the eradication of mistakes. He notes that "grammar instruction contributes to the error destabilization since it provides the learners with input, feedback, grammar explanation, and the opportunity for the learners to practice" (p. 39). He adds that errors only become fossilized when learners stop learning. That argument is sustained by Tarone (2012) when he writes that "bilingual speakers with arguably fossilized IL phonology or morphology have been shown to spontaneously shift to more target-line forms in language play producing "voices" in oral narratives" (p. 5).

As for stabilization, it is "a common phenomenon which can occur during a language learning process. Stabilization can be overcome as language developments proceed even though it can take a long time" (Lee, 2009). According to Selinker (1972), Stabilized errors often turn into fossilized ones.

Similarly, according to Huang (2009), interlanguage favors the emergence of many mistakes between the mother tongue and the target language. Nozadze (2012) discussed the causes of fossilization and summed them up as follows: Lack of correction Connection between interlanguage and errors - Method of instruction (too much based on the native language) - Errors that come from previous stages of learning (especially with older students) - Affective, cultural, cognitive and environmental perspectives of a language - Lack of motivation to correct oneself - Lack of strategies - Lack of learner autonomy - reliance on correction by teacher.

The issue of error correction has also been discussed in Lin (2019) in relation to Krashen's (1992) affective filter hypothesis. According to Lin, learners should be at the center of error correction. The author argues that traditional error correction techniques such as recast, explicit correction, repletion of errors are teacher-centered and ineffective. He notes that not putting students at the center of error correction can lead to psychological instability that could affect students' learning abilities.

In the same vein, Tercane \& Dikilitaş (2015) note anxiety as a significant factor that affects language learning and point to error correction as one of the leading factors. They discuss that "classroom teaching preferences and beliefs play a major role in the anxiety levels likely to be experienced by the students" (p. 25).

Lasagabaster \& Sierra (2005) report that although students want their corrected errors, they prefer selective error correction considering error correction moves resources and adequate correction strategies. 


\section{Methodology}

\subsection{Research design}

The author of this article uses a mixed-method approach to collect data for this study. According to Greene (2008), mixed-method "embraces multiple paradigmatic traditions and has or will have distinctive methodological components and distinctive markers of practice." (p. 20). Mixed methods research is based on a pragmatic worldview that "opens the door to multiple methods, different worldviews, and different assumptions as well as different forms of data collection and analysis" (Creswell 2009, p. 11). Given that mixed methods perspective, this study combines qualitative and quantitative data collection and data analysis methods.

The mixed-methods data collection strategy for this study is sequential exploratory. The researcher first collected data using qualitative data collection methods (classroom observations and interviews) before following up with a quantitative survey (Cameron, 2009).

\subsection{Study site and participants}

The study took place in local high schools in Ouagadougou, the capital city of Burkina Faso. The researcher researched four schools, two private schools and two public schools. This study participants were four English language teachers (two women and two men) and their high school students. Each teacher had about 40 to 50 students in the classroom. The students came from a diversity of socio-economic backgrounds and were all in premiere class (equivalent of 11th grade). The researcher chose that grade level because the students had already spent five full academic years learning English and were in their sixth year.

As for the teachers, they had a diversity of backgrounds. Two of them had five years of teaching experience, and the two others had 6 and 8 years of teaching experience. The two teacher participants with more than five years of teaching experience attended the teacher education school. They received initial teacher training, while the others did not. One of them, however, mentioned visiting teacher supervisors for their input in his teaching practices.

\subsection{Data collection procedures and methods}

Data collection occurred throughout a school year for nine months and concerned high school classrooms. The methods used to collect data are:

- Classroom observations;

- Interviews with teachers;

- Informal conversations with students;

- Focus groups with students;

- Questionnaires for students.

Data collection took place in four high school classrooms with four different EFL teachers. The teachers were all certified teachers of the local teacher education institution. 
Each class was observed once a week for two hours for three months. The researcher used the data collected during classroom observation to examine how teachers addressed and treated students' errors in their classes and the effect of such treatment on student learning.

Interviews with teachers and students followed classroom observations. The researcher interviewed each teacher once with the expectation of uncovering teachers' perception of students' errors. Each interview took 30 to 40 minutes.

As for students, they participated in a focus group discussion. The focus group included eight students (two students per class). It lasted 55 minutes and provided students with an opportunity to express their viewpoints about the treatment of their errors.

Another method of data collection was informal conversations with students. Those conversations often took place after classroom observations and consisted of elucidations of some of the data observed.

The last method of data collection was a survey addressed to two hundred students. The classroom representatives received the questionnaires and returned them filled out to the researcher two weeks later.

The data collection started with classroom observation and informal conversations followed by interviews and focus groups and ended with the survey. The interviews and the focus group consisted of open-ended questions that allowed the participants to discuss the issues at hand freely. The survey, however, was mostly made up of closedended questions that could generate numeric data.

\subsection{Data analysis}

The data analysis procedure used in this study was integrative. The analysis merged both qualitative and quantitative data (Creswell, 2009). It first consisted of a thematic analysis of data generated from the observations, informal conversations, interviews, and focus group. The analysis consisted of presenting excerpts of classroom observations of the different teacher participants. The informal conversations, interviews, and focus group data came in support of the classroom observations excerpts. The numerical data generated from the survey were then integrated into the themes.

\subsection{Trustworthiness}

In this study, trustworthiness was assured through the following criteria discussed by Guba \& Lincoln (1982): credibility, transferability, dependability, and confirmability.

As far as credibility is concerned, the researcher used triangulation of the multiple methods used to collect the data. Those methods were classroom observation, informal conversations, interviews, focus groups, and questionnaires. The use of multiple methods allowed the researcher to double-check the data collected.

As for transferability, it considered the diversity of participants. They had diversified backgrounds. The variety of the students' socio-economic background in this 
study and the teachers' professional experience allow the study's transferability to different settings in the country.

The research also used multiple methods to ensure reliability and dependability by confirming the complementarity of the data collected.

Finally, the researcher ensured confirmability by acknowledging her biases as a former teacher, a teacher educator, and a parent of high school students. Being aware of those biases allowed her to distance herself as much as possible from them and to design a trustworthy study.

\section{Findings}

The data analyzed in this study came from the methods of data collection mentioned in the methodology section. They consisted of addressing the research questions discussed in the introduction, respectively, teachers' perception and treatment of their students' errors and responses to error treatment.

Since English is a foreign language in Burkina Faso, it is common and easy to see students' errors. They were very much noticeable during classroom observations throughout the three months that they lasted. $90 \%$ of the students who participated in the survey reported making mistakes regularly. The remaining $10 \%$ of the student participants revealed preferring to remain quiet during English classes.

During classroom observations, the errors noted were diversified in nature and included pronunciation, grammatical, and communication issues. In the survey, $75 \%$ of the participants reported making pronunciation errors in English class, and 57\% reported making grammatical errors. Also, 50\% noted they resorted to codeswitching in French for communicative purposes.

In his 11th-grade classroom, teacher A dealt with a reading comprehension class on a text titled terrorism. He asked the students to read the text aloud. He interrupted the students every time there was a mispronunciation, which was at least on each sentence read. Some of the pronunciations corrected were on words such as 'hijacking', 'define', and 'organize'. The students read /hijakın/ instead of /hardzækın/, /define/ instead of /dı' fain/, and /organiz/ instead of /o:rgonaı/. Teacher A interrupted the students every time they mispronounced a word, pronounced the word correctly, and asked the student who mispronounced the word to repeat it before moving forward with the reading. The same procedure was noted in all the classes observed and did not vary whether it was reading or discussion.

It was also common for students to correct the mispronunciations of their peers. When one of their peers made an error, they repeated the correct form of the word, and the student then repeated it. For instance, in teacher B's class, a student read 'great'/grit/ instead of /greit/. As soon as he made the error, many voices in the classroom said /greit/. The student paused for a second and continued his reading without correcting his mispronunciation. Teacher B stopped him told him 'it's not/grit/it's/greit/ and the student repeated it. 
After class, the teacher showed the word 'great' to the same student and asked to pronounce it and, he pronounced /grit/. The researcher noted that although the students often successfully repeated the corrected pronunciation, they often made the same miss pronunciation error when they encountered the same word in the next sentence. All the student participants in the survey revealed that their teachers always corrected their errors in the classroom. $84 \%$ of them pointed out that their teachers often interrupted them to update their errors.

In a discussion with the teacher participants, they all admitted interrupting the students to correct their errors immediately. According to teacher $\mathrm{B}$, error correction is much more efficient when correction occurred immediately. He argued that "sometimes, students are not aware they made an error. If you let them finish and correct, they will not make a connection with what they said. But when you interrupt them, they realize their errors and correction is more useful".

The students have, however, held a different position during focus group discussions. Moses, one of the students, revealed that "when I am speaking, and the teacher stops me to correct my errors, I am confused" (translated from French). As for Ami, another student, "during my last English class, I raised my hand to talk about forced marriage". I said, "people marry young in the past." Then, the teacher stopped and said 'married.' I repeated married, but I did not understand.

The findings discussed above show that the teachers were very attentive to students' errors and resorted to teacher-centered approaches in their treatment of the students' errors. Following Lin's (2019), the teachers used traditional techniques to error corrections, which are inappropriate and ineffective. He argued that effective error correction techniques should be student-centered.

Besides, the teachers were quick at interrupting their learners and unveiled the forbidden nature of their classroom errors. Viewing students' errors as forbidden in the classroom seemed to deny their central role in language learning and acquisition (Lin, 2019). According to Nozadze (2012) errors are a part of language learning and should be treated accordingly.

Another teacher participant (teacher C) handed back papers and corrected a previously taken test by the student in his 11th-grade class. He called each student by name and handed back his/her exam, and made a class-wide comment about the students' work. In the following exerts, the teacher corrected some of the errors publicly. Teacher: "Biba!"

Biba stood up and walked to the teacher's desk. The teacher opened the paper of Biba, read, and wrote on the board. "I am agree"

Teacher (to the class): "Is this ok"?

The students all responded: "No."

Biba, still standing next to the teacher's desk, hid her face using her two hands.

Teacher: "I agree' you cross 'am.'"

He gave back Biba's paper, and she walked back to her seat. Then the teacher took another paper and Called Mike. While Mike was walking to his desk, he read from his paper, 
"We shall punish by God."

Mike arrives at his desk, took away his paper, and walked back to his seat. The teacher wrote the sentence on the board and then corrected it as follows.

"We shall be punished by God."

When she got back to her seat, Biba said to her neighbor, "I don't like what the teacher did. He does not need to tell my mistakes to the whole class" (translated from French). And the neighbor responded, "That's true. It hurts". I asked Biba why she hid her face when she was next to the teacher's desk, and she answered, "I was ashamed, and I felt stupid because I made that mistake" (translated from French). When I asked her if she knew why the teacher crossed 'am' from 'I am agree', she responded, no.

In another grade 11 classroom, teacher $\mathrm{D}$ had a class on the passive voice and was now having his students put sentences in the passive voice. He wrote sentences on the board gave them ten minutes to do the assignment, before proceeding to correction. He called up Issa and asked him to correct put the first sentence on the board. The sentence was:

"We sing our national anthem."

Issa walked to the board and wrote "our national anthem is sung by us".

The teacher took back the chalk, circled the word 'sung' and asked: is it 'sang' or 'sung'? a or $\mathrm{u}$ ?

But no one responded then he said it is ' $u$.'

During the interviews with teacher $C$ and teacher $\mathrm{D}$, they discussed that their approach in correcting the learner's errors were effective. Teacher $\mathrm{C}$ claimed that most of the time, the student's errors are due to being careless. He said, "these are things that they already know. If they just took some time to pay attention to what they write, they would not make those errors. I need to check them. That way, next time, they would be more careful if they face such a situation." As for teacher D, he said, "I know it could be hurtful, but that is how my teachers helped me when I still a student. It worked with me; it will work with them."

The findings revealed that error treatment in teacher D and teacher C's classes focused on humiliation. Both teachers ignored the affective factors that could favor or impede learning. The errors' treatment was teacher-centered and could be conducive to psychological issues that would affect learning abilities (Lin, 2019). The approach used to address students' errors could be a source of anxiety that, according to Tercane \& Dikilitas (2015), could affect language learning.

\section{Discussion}

This paper's discussion focuses on interlanguage theory, perceived as the development of a new linguistic system that is in-between the native language and the target language. Interlanguage then assumes that second language learners make mistakes in language acquisition and learning (Huang, 2009). The way the teacher treats the errors, however, determines how the learners overcome them. This paper then focuses on the concepts of 
fossilization developed by Selinker (1972) and stabilization developed by Selinker \& Lakshamana (1992) to discuss the findings.

An analysis of the errors addressed in this paper shows that they are mostly grammatical and pronunciation errors. Teachers' technique in correcting students' errors is mostly explicit correction, as Ellis, Loewen, and Erlam (2006) discussed as feedback pointing out the presence of an error. It was mostly the case for teachers $\mathrm{A}$ and $\mathrm{B}$, who explicitly pointed out and corrected their learners' pronunciation errors. Teachers $C$ and D resorted to elicitation techniques to address their learners' errors.

From an interlanguage perspective, the treatment given to students' errors could potentially foster stabilization and even fossilization. Teachers' explicit correction and elicitation inadequately addressed students' errors. The teachers neglected to deal with the causes of the errors. It seems evident that the pronunciation errors unveiled phonetic and phonology weaknesses. Instead of dealing with those weaknesses, the teachers assumed an explicit correction would help the learners. However, there is no evidence that such a correction technique could challenge the phonetic and phonology issues.

The same argument holds for the grammatical errors in the text. Although the teachers' elicitation technique could help identify the error, it is not necessarily conducive to remediation. Ami, one of the students, discussed mechanically repeating 'people married young in the past' instead of people marry young in the past.' She received a correction with no explanation. Such a correction was ineffective as she would keep making similar errors.

Referring to Fauziati (2011), the teachers have denied the learners opportunities to eradicate their errors through efficient pedagogical intervention. According to Lee (2009), stabilization occurs during language learning. It is essential to view it as a developmental process that could contribute to language learning if addressed appropriately. Unfortunately, the data provided in this paper show that the pedagogical interventions received by the learners were ineffective and could potentially turn the stabilized errors into fossilized ones (Selinker, 1972).

Another argument is that the treatment of learners' errors disregarded the psychological factors that affect language learning. The teachers used traditional error correction techniques, which, according to Lin (2019), are teacher-centered and ineffective. Lin argues that teacher-centered error correction can be conducive to psychological instability. In addition to the techniques used, error correction fostered anxiety, which according to Tercane \& Dikilitas (2015), affects language learning efficiency. Biba's case was an example of student frustration. Not only did she not understand the teacher's correction, but she also experienced anxiety, which could hinder her learning process.

The paper argues that the error treatment techniques and the psychological issues imposed on the learners favor the development of interlanguage through the emergence of mistakes (Huang, 2009). However, those mistakes could easily develop from stabilization to fossilization if teachers do not adopt more effective error correction approaches. Nozadze (2012) noted several causes of error fossilization: lack of correction, 
affective, cultural, cognitive, and environmental perspectives of a language, lack of motivation to correct oneself, lack of strategies, lack of learner autonomy, and reliance on correction by teacher. We can claim that the conditions are being put together in all four classes to fossilize students' errors. Unfortunately, the fossilization of errors might be disadvantageous to the learners since Selinker (1972) views it as permanent. It assumes that learning does not occur anymore (Long, 2003) and hinders language learning and language acquisition.

\section{Conclusion}

The data collected and analyzed in this study demonstrated that the teacher participants used teacher-centered techniques to address students' errors. Those techniques have proved ineffective as they were often isolated and not sustained by pedagogical interventions. Besides, error treatments disregarded students' psychological factors that can constitute a hindrance to language learning.

From an interlanguage perspective, the treatment to students' errors could affect language learning as they can be conducive to error stabilization and even error fossilization. By denying students pedagogical interventions and not considering psychological factors, teachers fail to assist their learners in improving their learning abilities. They are somewhat encouraging and perpetuating the errors made by their students. Such a treatment allows the errors to settle down and even become permanent. When errors become stable and even fossilized, it implies that learning does not happen any longer.

Teachers must develop positive attitudes towards their students' errors and adopt student-centered approaches to deal with them. Adopting student-centered approaches will minimize the psychological burden that hinders learning and favor learning abilities that will prevent fossilization.

\section{Conflict of Interest Statement}

The author declares no conflicts of interests.

\section{About the Author}

Dr. Esther Somé-Guiébré has been a teacher educator at Ecole Normale Superieure in Burkina Faso since 2013. She holds a Master in African studies and in Gender studies and a PhD from the department of Curriculum and Instruction at the University of Illinois Urbana Champaign (USA). She wrote her thesis and published articles on the challenges faced by African immigrant children in American classrooms. Currently, she has been working and publishing on issues regarding English as a foreign language, communicative competence, syllabus design, etc. Her research interest also includes multicultural education, post colonialism, and gender studies. She has been teaching courses on theories of second language acquisition, foreign language evaluation, language and education, and research methodologies. 


\section{References}

Al-khresheh, M. H., 2015. A review study of interlanguage theory. International Journal of Applied Linguistics and English Literature 4: 123-131. Doi: $\underline{10.7575 / a i a c . i j a l e l . v .4 n .3 p .123}$

Cresswell, J. W, 2009. Research design: Qualitative, quantitative, and mixed methods approaches. SAGE Publications, Inc.

Cameron, $R, 2009$. A sequential mixed model research design : Design, analytical and display issues. International Journal of Multiple research approaches $3: 140-152$. https://doi.org/10.5172/mra.3.2.140

Ellis, R., Loewen, S., Erlam, R, 2006. Implicit and explicit corrective feedback and the acquisition of L2 grammar. Studies in Second Language Acquisition, 28: 339-368. doi: https://doi.org/10.1017/S0272263106060141

Fauziati, E, 2011. Interlanguage and error fossilization: A study of Indonesian students learning English as a foreign language. Indonesian Journal of Applied Linguistics 1: 25-37.

Greene, J., 2008. Is mixed methods social inquiry a distinctive methodology? Journal of Mixed Methods Research 2: 7-22. https://doi.org/10.1177/1558689807309969

Guba, E.G., Lincoln, Y. S, 1982. Epistemological and methodological basis of naturalistic inquiry. Educational Communication and Technology Journal 30: 233-252.

Huang, Q., 2009. Accuracy and Fluency: Inspiration from error correction of interlanguage theory. Asian Social Science 5: 84-86

Han, Z, 2005. Fossilization in adult second language acquisition, Multilingual Matters.

Lasagabaster, D., Sierra, J. M, 2005. Error correction: Students' versus teachers' $\begin{array}{llll}\text { perceptions. } & \text { Language } & \text { Awareness } & \text { 112-127. }\end{array}$ https://doi.org/10.1080/09658410508668828

Lee, E. H., 2009. Issues in Fossilization and Stabilization. Linguistic Research 26: 149-168 Lin, L., 2019. Study on the Influence of Affective Factors on Error Correction in Chinese EFL Teaching. Advances in Social Science, Education and Humanities Research 356: 109-111.

Long, M., 2003. Stabilization and fossilization in interlanguage development. In Doughty, C. \& Long, M. (Eds.), The Handbook of Second Language Acquisition (pp. 487535). Malden, MA: Blackwell

Nozadze, A., 2012. Dealing with fossilized errors while teaching grammar. Journal of Education 1:41-46

Tarone, E., 2018. Interlanguage. In C. Chapelle (Ed). The Encyclopedia of Applied Linguistics. (pp. 1-7). John Wiley \& Sons.

Selinker, L., 1972. Interlanguage. International Review of Applied Linguistics in Language Teaching 10: 219-231.

Selinker, L., Lakshmanan, U., 1992. Language Transfer and Fossilization: The Multiple Effects Principle. In S. Gass, \& L. Selinker (Eds.), Language Transfer in Language Learning (Rev. ed., pp. 197-216). Philadelphia: Benjamins. 
Tercan, G, Kenan Dikilitaş, I. K, 2015. EFL students' speaking anxiety: a case from tertiary level students. ELT Research Journal 4: 16-27. to copy, distribute, transmit or adapt the article content, providing a proper, prominent and unambiguous attribution to the authors in a manner that makes clear that the materials are being reused under permission of a Creative Commons License. Views, opinions, and conclusions expressed in this research article are views, opinions, and conclusions of the author(s). Open Access Publishing Group and European Journal of Foreign Language Teaching shall not be responsible or answerable for any loss, damage, or liability caused in relation to/arising out of conflicts of interest, copyright violations, and inappropriate or inaccurate use of any kind content related or integrated into the research work. All the published works are meeting the Open Access Publishing requirements and can be freely accessed, shared, modified, distributed, and used in educational, commercial, and non-commercial purposes under a Creative Commons Attribution 4.0 International License (CC BY 4.0). 